\title{
DUKUN JALUR DESA SAIK KUANTAN
}

\author{
Andini Venydhea ${ }^{1}$, Mita Rosaliza ${ }^{2}$ \\ Universitas Riau, Pekanbaru \\ andiniimam1704@gmail.com ${ }^{1}$ \\ mita.rosaliza@lecturer.unri.ac.id ${ }^{2}$
}

\begin{abstract}
The Kuantan Singingi community still believes in the existence of fine creatures that inhabit a place or object that is quite old. One example is the wood of the Track, the Path itself is made of wood that has been aged for hundreds of years and comes from the jungle in the wood. This wood can only be taken by people who understand about Subtle Creatures, namely Jalur Shaman. The equipment used and the track assistants in the processed of the Jalur Shaman Rituals contain symbolic meaning, in the process the Jalur Shaman rituals are carried out by finding a good day of breaking to release the path to the Pacu jalur arena in order to get good draws, lime that has been incantated or prayed for and prayed for and kemeyan to call the Jalur ghost used in the Jalur Shaman Ritual as an effort Jalur Shaman Village Saik avoid attacks from Jalur Shaman opponents who try to harm the Jalur ghost, Jalur, and Pacu, in addition to chanting spells or prayers asking to be protected during the match the runway is aimed at Allah SWT, the mantra is also recited for the jalur ghost to help in Pacu Jalur competition. The existence of the Trust of Jalur Shamans in Saik Village is because there are still things that are magical in the Pacu Jalur competition, through the Ritual Treatment process of the jalur performed by the shaman believed to be able to protect the Jalur ghost, Jalur, and anak pacu from attacks from the opposing Shaman. The purpose of this study namely: (1) to find out the History of Line Shamans in Saik Village (2) to find out how the Ritual Treatment Procession of the Line (3) is to describe How to Trust Shaman Lane in Saik Village, Kuantan Mudik District, Kuantan Singingi District, Riau Province. As for the informants, the Shaman in Saik Village is considered to know about the Path Ritual and in depth. This research method is qualitative by using the theory of Sacred Durheim and Profane Theories, Carl Gustav Jung's Archetype Theory and Ferdinand de Saussure's symbolic theory.
\end{abstract}

Keywords: Dukun Jalur, Sacred, Rites

\section{PENDAHULUAN}

Kabupaten Kuantan Singingi

merupakan salah satu Kabupaten yang ada di Provinsi Riau yang mempunyai beragam Kebudayaan Tradisional. Budaya tradisional ini 
disebarkan secara lisan dan tulisan secara turun temurun. Salah satunya adalah Pacu Jalur. Pacu Jalur merupakan even yang tidak asing lagi bagi Masyarakat Riau. Setiap tahun, di Kabupaten Kuantan Singingi, di adakan kegiatan perlombaan Pacu Jalur ini. Setiap desa dan Kecamatan yang ada di Kabupaten Kuantan Singingi yang memiliki Jalur sendiri akan ikut serta dalam pertandingan. Beberapa daerah lain juga biasanya ikut meramaikan even, seperti Indragiri Hilir, Rengat dan berbagai daerah lainnya.

Pacu jalur yang awalnya memiliki latar konteks zamannya, sekarang telah berkembang menjadi perlombaan olahraga bertahap nasional. Ia juga menjadi salah satu ikon wisata Kabupaten Kuantan Singingi dan Provinsi Riau.

Namun, walaupun latar sosioekonomi Pacu Jalur telah berubah, beberapa tradisi lama masihlah melekat. Salah satunya adalah Dukun Jalur dan Prosesi Ritual yang mengiringi proses Pacu Jalur tersebut. Unsur magis masih kuat tertanam sebagaimana kepercayaan masyarakat setempat. Masyarakat lokal percaya bahwa kemenangan dalam perlombaan Pacu Jalur juga ditentukan oleh olah batin dari pawang perahu atau dukun perahu di samping kekuatan otot pendayungnya (Hasbullah, 2016).

Dukun jalur menjadi instrumen penting dalam Pacu Jalur, mulai dari proses pemilihan dan penebangan kayu untuk membuat jalur, pada proses keberangkatan jalur ke lokasi perlombaan hingga pada proses perlombaan itu sendiri.

Pada proses pengambilan kayu jalur diyakini bahwa kayu yang sudah berusia ratusan tahun memiliki penunggu. Oleh karena itu dibutuhkan orang yang bisa berkomunikasi dengan penunggu tersebut agar proses penebangan bisa berjalan lancar dan terhindar dari hal-hal yang tidak diinginkan.

Setelah kayu ditebang dengan 'izin penunggu' maka peran Dukun Jalur selanjutnya adalah melaksanakan ritual sebelum Jalur di berangkatkan ke lokasi perlombaan. Ritual ini di lakukan 
agar penunggu jalur, Jalur, dan Anak Pacu terlindungi dari gunaguna kiriman Dukun Jalur Lawan.

Jalur, Penunggu Jalur, Anak $P a c u$, Dukun Jalur, Panitia Jalur dan masyarakat desa adalah unsur-unsur penting dalam upacara Pacu Jalur. Semua unsur itu saling berkaitkelindan satu sama lain menjadi satu kesatuan yang utuh, yang apabila ada unsur yang kurang maka akan terjadi ketimpangan. Dukun Jalur menjadi unsur paling penting.

Masyarakat setempat meyakini bahwa Jalur yang dibentuk dari pohon yang berusia puluhan bahkan ratusan tahun itu diibaratkan makhluk yang memiliki roh dan raga. Jalur adalah raganya sedangnya rohnya diisi oleh penunggu jalur. Agar antara raga dan roh tetap menyatu maka Dukun Jalurlah yang menjadi 'pembujuk'nya. Proses 'pembujukan' itu disebut dengan Ritual Jalur. Selain untuk keseimbangan roh dan raga antara Jalur dan Penunggu Jalur, Ritual Jalur juga dimaksudkan untuk meminta Penunggu Jalur 'bekerja sama' dalam proses pemenangan acara perlombaan sebagaimana yang diharapkan Panitia Jalur dan masyarakat pemilik jalur tersebut. Ritual Jalur juga bertujuan untuk melindungi Jalur, Penunggu Jalur dan Anak Pacu. Bahwa kepercayaan pada hal mistis sudah menjadi kepercayaan kolektif masyarakat pemilik Jalur dari berbagai desa di Kuantan Singingi tersebut. Masing-masing desa akan memakai Dukun Jalur. Tak jarang pula ada Dukun Jalur yang bertindak tidak sebagaimana mestinya. Ia berperan tidak hanya untuk menjaga keselarasan dan kesatuan kosmos antara manusia dan alam yang diwakili lewat Jalur, Penunggu Jalur dan Anak Pacu, namun juga menjadi pengganggu bagi Jalur lain di pihak lawan. Untuk menghindari 'serangan tak tampak' dari Dukun Jalur lain itulah Ritual Jalur perlu dilaksanakan. Dukun Jalur juga bertindak sebagai pelindung bagi Jalur, Penunggu Jalur dan Anak Pacu.

Bunga-bunga, limau dan kemenyan yang dibakar menjadi 
media yang digunakan Dukun Jalur dalam melaksanakan Ritual Jalur. Praktek seperti ini sudah dilakukan masyarakat setempat jauh sebelum Islam datang. Jika ditilik dari sudut aqidah ajaran Islam tentu hal ini sangat bertentangan. Namun, persoalannya disini adalah bagaimana keyakinan serta praktik ritual berintregrasi dengan agama (islam) (Ismail, 2012). Kedudukan Dukun Jalur dalam kehidupan sehari-hari sama dengan masyarakat lainnya yaitu sebagai kepala keluarga, mencari nafkah untuk keluarganya. Mereka juga mempunyai profesi lain seperti penakik getah, pedagang dll.

Fenomena Dukun Jalur dengan segala aspek yang melingkupinya menjadi menarik untuk dikaji dengan sudut pandang humaniora. Hal inilah yang menjadi latar belakang dari penelitian ini.

Dari sekian banyak desa yang turut serta dalam Pacu Jalur, maka desa yang dijadikan sample adalah Desa Saik. Desa Saik beberapa kali meraih peringkat lima besar dalam perlombaan Pacu Jalur di Kabupaten Kuantan Singingi.

Masyarakat Desa Saik hingga sekarang masih menganut kepercayaan orang-orang dulu dalam melakukan Ritual Jalur.

Masyarakat Saik menyerahkan segala perhitungan yang bersifat magis dan mistis kepada Dukun Jalur. Misal, dalam menentukan hari keberangkatan Jalur menuju arena pertendingan. Hari yang dipilih mestilah berdasarkan 'pembacaan' sebelumnya oleh Dukun Lajur berdasarkan Simbol Hari dengan hitungan Weton dan juga Petanda Mimpi. Setelah hari keberangkatan Jalur ditetapkan maka diiringi dengan doa-doa dalam Bahasa Melayu, Minangkabau dan Jawa, juga doa-doa dari ayat Alquran.

Semua ritual itu dilakukan demi kemenangan Jalur Desa Daik dalam perlombaan Pacu Jalur yang akan diikuti. Karena konon, jika semua langkah dalam ritual itu dilakukan dengan baik dan sempurna maka keselarasan dan kesatuan akan terbentuk sehingga Penunggu Jalur, Jalur, Anak Pacu 
dan Para Pendayung energinya akan menyatu. Jalur menjadi ringan dan laju dikayuh hingga garis Finish.

\section{TEORI}

Durkheim mendefinisikan agama dari sudut pandang "yang sakral" (Sacred). Ini berarti "agama adalah kesatuan sistem keyakinan dan praktek-praktek yang berhubungan dengan suatu yang sakral. Sesuatu yang disisihkan dan terlarang, keyakinan-keyakinan dan praktek-praktek yang menyatu dalam suatu komunitas moral yang disebut Gereja, di mana semua orang tunduk kepadanya" (Pals, 2011) Durkheim mengatakan, konsentrasi utama agama terletak pada "yang sakral", karena memiliki pengaruh luas, menentukan kesejahteraan dan kepentingan seluruh anggota masyarakat. Yang profan tidak memiliki pengaruh yang begitu besar dan hanya merupakan refleksi keseharian dari setiap individu. Maka, Durkheim mengingatkan bahwa dikotomi tentang "yang sakral" dan "yang profan" hendaknya tidak diartikan sebagai sebuah konsep pembagian moral, bahwa yang sakral sebagai "kebaikan" dan yang profan sebagai "keburukan". Menurut Durkheim, kebaikan dan keburukan sama-sama ada dalam "yang sakral" ataupun "yang profan". Hanya saja yang sakral tidak dapat berubah menjadi profan dan begitupula sebaliknya yang profan tidak dapat menjadi yang sakral. Dari definisi ini, konsentrasi utama agama terletak pada hal-hal yang sakral (Pals, 2011).

Berdasarkan Teori Durkheim tentang yang Sakral dan yang Profan, maka Pacu Jalur dengan segala ritual yang menyertainya tergolong ke dalam hal yang Sakral. Bagian-bagian seperti berdoa atau membaca mantra demi keselamatan dalam bertanding, proses komunikasi dengan penunggu jalur, penentuan hari baik keberangkatan Jalur menunjukkan hal yang sakral tersebut.

Semiotika atau semiologi adalah metode yang dipakai untuk menganalisis tanda-tanda atau signs 
(Ida, 2014). Menurut Ferdinand De

Saussure, tanda berhubungan dengan realitas hanya melaui konsep-konsep dari orang-orang yang menggunakannya (Fiske, 2012). Tanpa adanya konsep dalam pikiran manusia, maka sebuah tanda tidak memiliki makna. Melalui semiotika, kita dapat mempelajari bagaimana manusia memaknai halhal atau tanda-tanda disekitarnya. Salah satu tokoh penting semiotika adalah Ferdinand De Saussure. Saussure merupakan seorang ahli bahasa, sehingga dia lebih berfokus pada bagaimana tanda-tanda (dalam konteks Saussure adalah kata-kata) terkait dengan tanda-tanda lain.

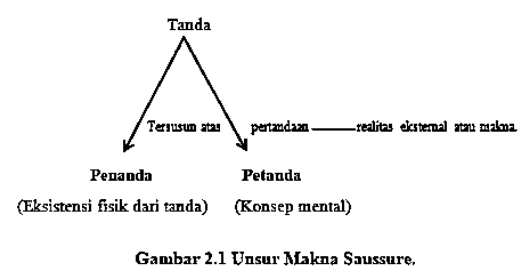

Dari tiga model makna tanda di atas, dapat ditarik kesimpulan bahwa tanda merupakan sesuatu yang bersifat fisik, bisa dipersepsi oleh panca indra; tanda mengacu pada sesuatu di luar tanda itu sendiri; dan bergantung pada pengenalan oleh penggunanya sehingga bisa disebut tanda (Bungin, 2007).

Selain menggunakan Teori Durkheim tentang yang sakral dan profan, peneliti juga menggunakan semiotika Roland Barthes. Teori ini digunakan untuk mengungkap dan mencari representasi makna simbolik dari segala perangkat dan langkah-langkah dalam Ritual Jalur di Desa Saik.

Sebuah kata atau gambar dianggap bersifat simbolis ketika ia mengisyaratkan sesuatu di luar maknanya yang dekat dan nyata. Ia memilki aspek aspek "bawah sadar" yang lebih luas, yang tak pernah terdefinisi secara pasti dan tak bisa di jelaskan sepenuhnya. Saat pikiran menelusuri simbol menelusuri simbol ia akan menuntun kita menuju gagasan-gagasan yang terletak jauh pada logika. Namun penggunaan simbol-simbol secara sadar seperti ini hanyalah salah satu dari aspek dari fakta psikologis lain yang sangat penting: bahwa manusia menciptakan pula simbol-simbol secara spontan dan di luar 
kesadaran yakini dalam bentuk mimpi (Jung, 2018 ).

Jung menggunakan istilah citra primordial (primordial images). Beberapa citra bersumber dari pengalaman universal, seperti pengalaman yang dialami oleh kebanyakan manusia, melalui pengulangan pada kehidupan generasi selanjutnya. Arketipe dalam psyche dimunculkan dalam mimpi dan fantasi. Arketipe-arketipe tersebut adalah pahlawan, ibu, anakanak, Tuhan, kematian, kekuatan, atau orang tua yang bijak (Hidayat, 2011).

Jung lebih menekankan alam bawah sadar kolektif dan menggunakan pengalamanpengalaman personal untuk memperkuat kepribadian total. Sehingga Jung meletakkan alam bawah sadar kolektif sebagai dayadaya otonom yang disebut arketipe. Beberapa arketipe yang pokok adalah topeng (persona), sisi jahat dari aku (shadow), sifat kewanitaan dalam keperiaan dan sifat keperiaan dalam wanita (anima dan animus), aku (self).
Teori Arketipe adalah teori berikutnya yang digunakan untuk memahami Ritual Jalur Desa Saik. Bagian ritual tentang kepercayaan bahwa mimpi Dukun Jalur adalah petunjuk dapat didekati dengan Teori Arketipe ini. Masyarakat setempat percaya jika yang datang pada mimpi Dukun Jalur adalah petunjuk atas langkah yang mesti dipilih. Jika yang datang dalam mimpi Dukun Jalur adalah binatang buas maka itu diyakini sebagai petanda akan ada hal buruk akan terjadi. Mimpi tersebut juga dimaknai sebagai peringatan agar masyarakat Desa Saik tidak melanggar pantang larang mereka. Sosok orang tua yang sudah meninggal atau juga leluhur kampung juga kerap hadir dalam mimpi Dukun Jalur. Biasanya sosok-sosok ini datang untuk memberi nasehat juga memberi tahu pelangkahan yang baik untuk memberangkatkan jalur ke arena perlombaan.

\section{Mana pada Dukun Jalur}


Menurut James E.O pada artikelnya "mana and fetishism" dalam chambers' encylopaedia menyebutkan mana sebagai suatu istilah dari penduduk asli daerah Pasifik yang berarti "kekuasaan gaib yang rahasia atau pengaruh yang mengikat benda-benda tertentu kemudian menjadikan benda-benda itu suci dan tabu, seperti jangan mudah didekati, awas, hati-hatilah terhadapnya dan sebagainya. Corington mengatakan bahwa mana adalah suatu kepercayaan terhadap adanya sesuatu kekuatan yang sama sekali berbeda dengan kekuatan fisik, sesuatu kekuatan yang menonjol, menyimpang dari yang biasa, luar biasa dan adi kodrati (Daradjat, 1996).

Menurut Codrington mana selalu ada hubungannya dengan seseorang atau sesuatu, ini berarti bahwa mana tidak pernah terlepas dari sesuatu. Ia tidak pernah disembah, akan tetapi sesuatu yang ketempatannya dan mengandungnya lah yang disembah, disucikan dihormati atau bahkan juga ditakuti, makanya dihindari katena tabu,
Kalau mana itu bertempat pada seseorang, maka orang itu akan mempunyai keistimewaankeistimewaan yang mengherankan orang. Biasanya oaring ini menjadi atau terdiri dari kepala suku, pimpinan perang, dukun dan orang suci. Jikalau seseorang itu lebih berhasil dalam berbagai usahanya dibandingkan dengan orang lain yang sepadan dengan dia, itu dianggap karena ia mempunyai mana yang lebih tinggi kadarnya dari orang lain (Daradjat, 1996).

Dukun Jalur memilki mana nya sendiri semisal dalam melepaskan jalur menuju gelanggang dan ancang-ancang setelah selesai membacakan doa mengobat jalur dengan menggunakan air limau dan membakar kemeyan. Tangan dukun jalur yang turut mendorong jalur dianggap memiliki mana yang hanya dimiliki oleh Dukun Jalur seorang saja.

\section{METODE}


Metode yang digunakan dalam penelitian ini adalah metode penelitian kualitatif deskriptif. Pemilihan metode ini berdasarkan beberapa pertimbangan, Pertama, metode kualitatif lebih mudah apabila berhadapan dengan kenyataan ganda; kedua, metode ini menyajikan secara langsung hakikat hubungan antara penelitian dengan objek penelitian; ketiga, metode banyak penajaman pengaruh bersama terhadap pola nilai yang di hadapi (Moleong, 2013).

Subyek penelitian adalah orang-orang yang dianggap bisa menjawab rumusan masalah yang akan diteliti serta terlibat dalam hal yang akan di bahas peneliti tentang Dukun jalur Desa Saik di Kuantan Mudik, Kabupaten Kuantan Singingi, Provinsi Riau yaitu sebagai berikut :

- Bapak Suwodo selaku Dukun jalur Desa Saik di Kuantan Mudik, Kabupaten Kuantan Singingi

- Tok Suman selaku Dukun jalur Desa Saik di Kuantan
Mudik, Kabupaten Kuantan Singingi

○ Tok Munir selaku Dukun jalur Desa Saik di Kuantan Mudik, Kabupaten Kuantan Singingi

- Bapak Mizi Selaku Dukun jalur Desa Saik di Kuantan Mudik, Kabupaten Kuantan Singingi

Objek penelitian ini adalah Dukun jalur Desa Saik di Kuantan Mudik, Kabupaten Kuantan Singingi dengan segala aspek yang melingkupinya seperti sejarah dan kepercayaan Dukun Jalur serta proses-proses Ritual Jalur yang dilakukan oelh para Dukun Jalur.

\section{PEMBAHASAN}

Jalur Desa Saik pertama kali memisahkan diri dan mendirikan jalur sendiri pada tahun 2007. Dulunya Desa Saik adalah bagian dari Desa Banjar Kuantan, lalu di pisah menjadi 3 desa pada tahun 1971. Nama yang diberi pada jalur Desa Saik ini adalah Delima Indah 
Permata Kuantan. Jalur ini banyak menoreh prestasi dan juga menjadi jalur yang patutu perhitungkan dari Kuantan Mudik.

Dalam Pacu Jalur Desa Saik terdapat hampir 53 Anak Pacu. Ditambah beberapa orang cadangan, 2 Anak Onjay atau Penari dan 4 orang Dukun Jalur. Diyakini juga ada dua penunggu jalur yaitu Saisun dan Raisun.

Jalur Delima Indah Permata Kuantan Desa Saik pernah menjadi juara. Namun sebagaimana pengakuan ketua pengurus jalur, dari 2015-2017 mereka tidak memakai dukun jalur. Akan tetapi atas permintaan masyarakat setempat mulai dari 2018 hingga sekarang mereka kembali menggunakan Dukun Jalur.

Berikut tabel perolehan juara oleh jalur Delima Indah Permata
Kuantan:

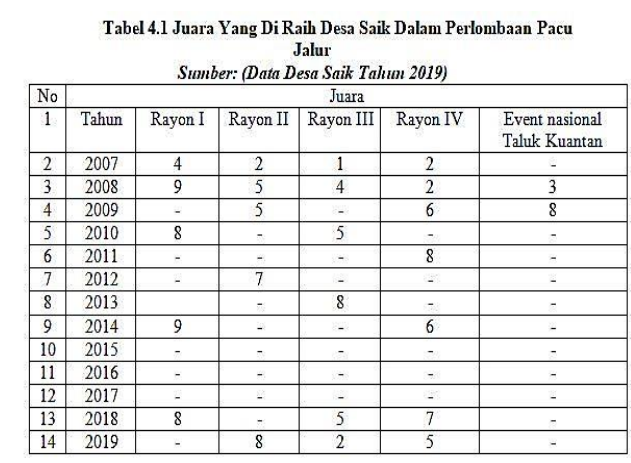

Berdasarkan tabel di atas dapat dilihat bahwa Jalur Delima Indah Permata Kuantan menjadi salah satu jalur yang diperhitungkan oleh jalur lawan.

\section{Sejarah Dukun Jalur}

Berdasarkan wawancara dengan empat informan penelitian, informasi yang peneliti peroleh bahwa kepercayaan terhadap Dukun Jalur dengan segala ritual yang menyertainya sudah menjadi tradisi masyarakat Desa Saik. Masyarakat percaya bahwa alam tidak hanya dihuni manusia saja tapi juga makhluk non-manusia. Antara keduanya mestilah terjadi keselarasan. Manusia mesti memiliki kesadaran bahwa alam bukanlah milik ia semata namun 
juga ada 'pemilik lain'. Oleh karena itu dialog mesti selalu dipelihara. Dukun Jalur dalam hal ini menjadi perantara dialog tersebut. Ketika pohon hendak ditebang untuk membuat jalur, maka Dukun Jalur mesti mengkomunikasikan terlebih dahulu pada Penghuni Pohon. Setelah persetujuan diperoleh barulah proses penebangan dilakukan. Selain itu Dukun jalur nantinya juga akan bertugas untuk 'mengobati' jalur dan Anak Pacu jika mendapat serangan dari dukun lawan.

\section{Persyaratan sebelum Ritual Dukun Jalur}

Salah satu hal penting dalam Ritual Jalur adalah Penentuan Hari Pelangkahan. Ada beberapa cara penentuan hari pelangkahan ini. Pertama, berdasarkan Perhitungan Hari Bulan yang kemudian dihitung dengan perhitungan tertentu sehingga didapatlah jam keberangkatan jalur.
Berikut tabel pelangkahan yang dipakai Tok Suman:

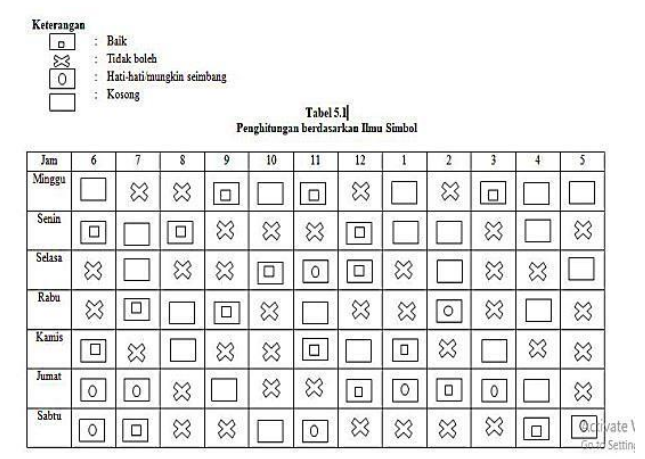

Kedua, penentuan hari pelangkahan berdasarkan mimpi. Dukun Jalur melaksanakan sholat istikharah dan mengamalkan beberapa doa untuk memohon petunjuk kepada Allah. Jawaban biasanya datang melalui mimpi. Namun, kadang mimpi antara Dukun Jalur bisa berbeda. Misalnya pada mimpi Pak Mizi dan Tok Suman. Mereka sudah melakukan ikhtiar yang sama. Mereka juga sama-sama bermimpi. Namun petanda dalam mimpi mereka berbeda.

Ketiga, penentuan berdasarkan Ilmu Hitungan Jawa menurut Weton. Pelangkahan ini merupakan ilmu yang di pakai Pak Suwodo 
dalam mengambil langkah untuk memberangkatkan Jalur.

\section{Peralatan Ritual Dukun Jalur}

Sehari sebelum Lomba Pacu Jalur, Dukun Jalur biasa nya akan melakasanakan ritual dengan menggunakan perangkat limau dan kemenyan sebagai syarat.

- Limau

Limau digunakan oleh Dukun Jalur sebagai perantara untuk mengobati jalur. Diharapkan limau ini sebagai pemersatu antara penunggu jalur dengan Anak Pacu. Doa-doa juga dibacakan sebagai bentuk transfer energi pada penunggu jalur dan anak pacu.

Gambar 5.1 Limau

Untuk Ritual Jalur

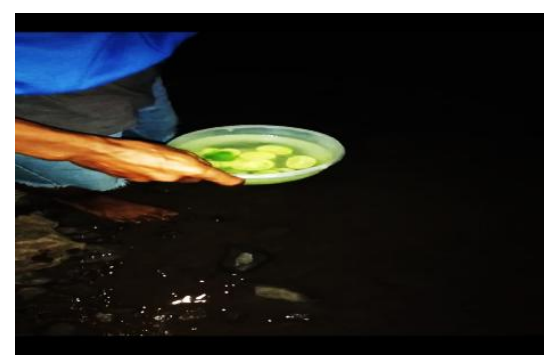

Sumber: (Data Peneliti, 2019)
- Kemenyan

Kemeyan dibakar. Setelah itu doa dipanjatkan kepada Allah. Arwah leluhur dan penunggu jalur dipanggil. Pembakaran kemenyan dimaksudkan agar pemanggilan arwah leluhur dan penunggu jalur berjalan lancar.

Gambar 5.2 Dukun Jalur Membakar Kemenyan Dalam Ritual Jalur

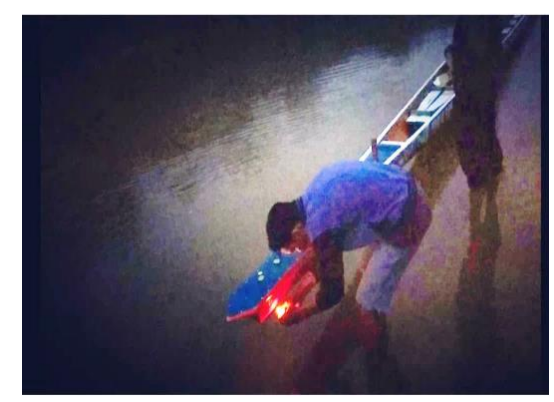

Sumber: (Data Peneliti, 2019)

- Bunga-bunga

Bunga-bunga ini tergantung dari permintaan dari Penunggu Jalur. Jikalau ia meminta maka akan di kabulkan, namun jika tidak maka bungabungaan tidak perlu disediakan. Menurut Pak Suwodo makluk mistis lebih menyukai wewangian sebagai 
tanda menyatakan eksistensi dirinya.

\section{Pelaksanaan Ritual Jalur}

Dukun jalur yang melakukan ritual ini ingin agar dalam perlombaan pacu jalur nantinya Penunggu Jalur serta Anak Pacu dapat terlindungi dari segala macam marabahaya dari pihak lawan dan berbagai kendala lainnya.

Berikut tata cara pelaksanaan ritual mengobat jalur yang dilakukan oleh Tok Suman:

- Pertama, penentuan hari pelangkahan atau pelepasan jalur menuju gelanggang. Proses perhitungan dilakukan Dukun Jalur tiga hari sebelum pelepasan jalur menuju gelangang.

- Kedua, ketika hari pelepasan jalur dan jam pelepasan jalur telah ditentukan maka Dukun Jalur berangkat menuju Sungai Kuantan di Desa Saik dengan membawa peralatan mengobat jalur berupa limau dan kemenyan
- Selanjutnya, Dukun Jalur mengambil air sungai di dalam wadah kemudian memasukkan limau yang telah dipotong tipis bulat ke dalam wadah tersebut. Lalu air limau tadi dibacakan doa.

Adapun doa yang diucapkan oleh Dukun Jalur yaitu sebagai berikut:

$$
\begin{aligned}
& \text { "Padareh Allah, } \\
& \text { Padareh Muhammad, } \\
& \text { Padareh Baginda ali, } \\
& \text { dan Rasullah ko ta } \\
& \text { pasak lai lokang kok } \\
& \text { takabuek lai ungkai ko } \\
& \text { ta kunci tangga } \\
& \text { Insyaallah Tuhan nak } \\
& \text { lalui Tablikum" } \\
& \text { (Wawancara dengan } \\
& \text { Tok Suman pada Jumat } \\
& \text { 03 Mei 2019 Pukul } \\
& \text { 17.00 Wib) }
\end{aligned}
$$

Setelah doa ini dibacakan barulah air limau tadi disiram ke seluruh badan jalur hingga sampai kepala jalur. Setelah air limau terakhir habis disiram, maka kepala jalur dipegang dan dibacakanlah doa pelepasan jalur. Doa tersebut sebagai berikut : 
"Bismilahhirrahmannir rahim kab dari Bumi, Ali dari langik, jiko buruak togah aku, jiko baik suruah aku aku melangkahkan langkah ali hu allah" (Wawancara dengan Tok Suman pada Jumat 03 Mei 2019 Pukul $17.00 \mathrm{Wib})$

Setelah doa pelepasan jalur dibaca maka dibaca lagi doa untuk Penunggu Jalur dengan bunyi sebagai berikut:

$\begin{array}{lr}\text { "Hai Niniak Saisun } \\ \text { Raisun kami ka } \\ \text { menurunkan jalur palo, } \\ \text { hari itu tolong Niniak } \\ \text { antar kami ketempat } \\ \text { perpacuan tetap Niniak } \\ \text { di situ. } & \text { Berkat } \\ \text { Lailahaillah, } & \text { sampai } \\ \text { sesudah di } & \text { tunggu" } \\ \text { (Wawancara } & \text { dengan } \\ \text { Tok Suman pada Jumat } \\ \text { 03 Mei 2019 Pukul } \\ \text { 17.00 Wib) }\end{array}$

Setelah itu barulah jalur dilepaskan menuju arena perlombaan.

Bagi Dukun Jalur sendiri, ia mesti pula melakukan amalan tertentu sebelum ia berangkat ke arena. Amalan tersebut yaitu:

1. Sholat istiqaroh yang dilaksanakan sebelum berangkat ke arena pacu jalur.

2. Membaca syahadat 100 kali

3. Membaca solawat nabi 100 kali

4. Membaca al-fatihah 7 kali

5. Membaca Doa Pagar Diri untuk diri dukun jalur dan juga Anak Pacu dengan niat dalam hati :

"kun kata Allah,
Fayakun kato
Muhammad, takkan
mati kato Allah, takkan
biso kato Muhammad
kato allah, kato
Muhammad,
perlindungan kan lah
anak pacu delima indah
permata kuantan dan
hamba lailahaillawlah"
(Wawancara dengan
Tok Suman pada Jumat
03 Mei 2019 Pukul
17.00 Wib)

Setelah amalan ini dilakukan barulah Dukun Jalur berangkat menuju Arena Perlombaan Pacu Jalur. Sesampai di arena biasanya ia terus membacakan sholawat dan juga doa pagar diri untuk Penunggu 
Jalur dan Anak Pacu. Tugas Dukun

Jalur masih terus berlanjut hingga

perlombaan berlangsung. Ia akan memantau jalannya lomba dan turut 'mendampingi' jalur desa mereka dengan ilmu kebatinan yang dimiliki. Dengan bantuan ilmu kebatinan itu diyakini bahwa jalur mereka akan terasa ringan dan para Anak Pacu memiliki tenaga ekstra yang memnuat mereka tidak lekas lelah.

Selain itu, sebagaimana yang diinfokan oleh Tok Suman sebagai Dukun Jalur, ia juga berusaha semaksimal mungkin untuk kemenangan jalur mereka dengan memanjatkan doa yang diambil dari ayat Alquran. Doa itu dibaca untuk menenggelamkan jalur lawan. Berikut doa yang di bacakan Tok Suman untuk pihak lawan :

"Waja'alnaa mimbaini aidihim saddaw wamim khalfihim saddaw fa aghsyanahum fahum laa yubshiruun" (Wawancara dengan Tok Suman pada Jumat 03 Mei 2019 Pukul $17.00 \mathrm{Wib})$
Artinya, Allah SWT memberi palang dihadapan mereka begitu pula di belakang, lalu Allah menutup mereka sehigga mereka tak dapat melihat.

Ayat tersebut merupakan ayat yang diambil dari doa dan tahlil ayat 9 . Selain itu juga ayat 43 yang di ambil:

$\begin{array}{lr}\text { "wa } & \text { innasya } \\ \text { 'nughiqhuum } & \text { falaa } \\ \text { shariikha } & \text { lahuum } \\ \text { walaahuum } & \\ \text { yungqadzuun" } & \\ \text { (Wawancara dengan } \\ \text { Tok Suman pada Jumat } \\ \text { 03 Mei 2019 Pukul } \\ \text { 17.00 Wib) }\end{array}$

Artinya, apabila kami dikehendaki kami karamkan mereka, maka takkan ada orang yang menolong dan mereka tidak akan lah selamat.

Dukun Jalur Lawan biasanya juga berikhtiar pula untuk kemenangan mereka dengan mengirimkan Guna-Guna kepada Anak Pacu. Jika hal itu terjadi, maka 
Dukun Jalur Desa Saik akan mengobati Anak Pacu.

Berikut wawancara peneliti dengan Tok Suman mengenai hal tersebut:

$$
\begin{aligned}
& \text { "ya kita sebagai orang } \\
& \text { tua tentu melindungi } \\
& \text { anak pacu di bacakan } \\
& \text { doa-doa kalo kena hal } \\
& \text { macam tu biar sembuh } \\
& \text { anak pacu kita, kadang } \\
& \text { di kasi minum air yang } \\
& \text { sudah atok baca-baca } \\
& \text { kan doa, doa yasin } \\
& \text { biasanya atok bacakan } \\
& \text { kan biar lekas sembuh } \\
& \text { sakit nya bisa lekas } \\
& \text { main pacu tu. kalo kena } \\
& \text { nya dalam perahu ya } \\
& \text { kita obati dengan } \\
& \text { meminum kan air yang } \\
& \text { dalam perahu tadi kan } \\
& \text { sudah di obat jalur nya } \\
& \text { sebelum ke gelanggang } \\
& \text { insyaallah sembuh lah } \\
& \text { anak pacu kita." } \\
& \text { (wawancarar dengan } \\
& \text { Tok Suman pada Jumat } \\
& \text { 03 Mei 2019 Pukul } \\
& \text { 17.00 Wib) }
\end{aligned}
$$

Berdasarkan wawancara di atas dapat dilihat bahwa Tok Suman mengobati Anak Pacu dengan cara memberikan air yang sudah dibacakan yasin. Hal ini sudah di siap kan Tok Suman untuk berjagajaga. Perlindungan juga diberikan kepada Penunggu Jalur dengan doa pagar diri.

\section{Analisis Teori Durkheim Pada Kepercayaan Dukun Jalur}

Kepercayaan Dukun Jalur dalam hal ini terlihat dalam kebudayaan Ritual Jalur yang di lakukannya. Ia melakukan ritual untuk meminta bantuan kepada penunggu jalur yang merupakan makluk halus yang mendiami jalur agar bisa meringankan jalur. Dukun Jalur melakukan ritual dengan limau, kemenyan dan juga bungabunga bila diminta oleh penunggu jalur. Benda-benda tersebut dibacakan mantra-mantra atau doadoa.

Kepercayaan akan penunggu jalur merupakan bagian yang 'sakral' sebagaimana yang dimaksudkan teori Durkheim. Ada hal yang tak tampak namun diyakini adanya. Hal yang tak tampak itu dianggap bisa menjalin relasi baik atau buruk dengan manusia 
tergantung sikap dan perbuatan manusia terhadapnya. Dalam konteks Ritual Jalur, maka relasi yang dibangun adalah relasi baik dimana Dukun Jalur melakukan proses komunikasi dengan makhluk halus penunggu jalur dengan bahasa 'bujukan'.

Transfer 'Spirit' oleh Dukun Jalur kepada Anak Pacu juga merupakan bagian 'sakral'. Anak $P a c u$ terjaga stamina dan semangatnya berkat doa-doa dan sugesti ilmu kebatinan dari Dukun Jalur mereka. Jalur, Penunggu Jalur, Anak Pacu akhirnya menjadi satu kesatuan yang utuh yang saling bekerjasama satu sama lain demi memperoleh kemenangan yang diharapkan bersama.

Selain hal yang 'sakral' juga terdapat hal 'profan' dalam Ritual Jalur ini. Hal itu terlihat pada pantang larang dalam perlombaan. Salah satu larangan bagi Anak Pacu adalah tidak boleh buang air kecil di dalam jalur. Larangan ini bisa dimaknai sebagai sesuatu yang 'profan'. Hal profan yang dapat dilihat bahwa pada dasarnya kencing di jalur merupakan hal biasa bagi orang lain khususnya yang bukan Anak Pacu. Sebuah jalur pasti terisi air maupun itu dari air sungai maupun air kencing tidak ada bedanya antara itu kerena air kencing dan air sungai bersifat sama yaitu air. Bagi orang biasa tentunya ini dianggap bukan hal yang berpengaruh bagi jalur antara bisa kalah atau celaka karena kencing di perahu.

\section{SIMPULAN}

Berdasarkan penelitian dan pembahasan yang telah dilakukan dalam prosesi Ritual Dukun Jalur Dan Kepercayaan Dukun Jalur di Desa Saik, Kecamatan Kuantan Mudik, Kabupaten Kuantan Singingi, Provinsi Riau diperoleh kesimpulan terdapat arketipe Dalam Penandaan Mimpi Dukun Jalur. Di setiap mimpi memilki arti yang dialami di alam bawah sadar.

Persoalan Sakral dan Profan juga terdapat dalam Ritual Dukun Jalur. dan kepercayaan dukun jalur juga ada di dalam nya berupa yang 
sakral dapat di temui pada penunggu jalur yang tidak dapat dilihat di sentuh oleh orang biasa melain kan orang yang paham dan bisa menjagakau nya yaitu dukun jalur namun hal profane bisa juga menyentuh yang sakral misalnya saja anak pacu yang juga bisa merasakan sakit ketika penunggu jalur terkena guna-guna dari lawan maka Anak Pacu juga terkena hal yang demikian.

Penanda yang ada pada Penunggu Jalur di Desa Saik yaitu Saisun Dan Raisun juga ada pada tanda pemikiran Dukun Jalur orang bisa melihat, berkomukasi dan meminta pertolongan kepada Penunggu Jalur untuk bisa membantu dalam pertandingan pacu jalur. Dukun jalur percaya bahwa Penunggu Jalur bisa menolong untuk meringankan dalam pertandingan pacu jalur dengan berkomunikasi dan membacakan mantra kepada penunggu jalur sehingga bisa membantu dukun jalur dalam pertandingan pacu jalur, selain itu dukun jalur juga melakukan ritual untuk melindungi jalur, Penunggu Jalur dan Anak Раси agar tidak terkena guna-guna dari Dukun Jalur Lawan.

\section{DAFTAR PUSTAKA}

Bungin, B. 2007. Penelitian Kualitatif: Komunikasi, Ekonomi, Kebijakan Publik dan Ilmu Sosial Lainnya. Jakarta: Kencana.

Daradjat, D. Z. 1996. Perbandingan Agama I. Jakarta: Bumi Aksara.

Fiske, J. 2012. Pengantar Ilmu Komunikasi. Jakarta: PT. Raja Grafindo.

Hasbullah. 2016. Unsur-Unsur Magis dalam Tradisi Pacu Jalur: Prespektif Antropologi Agama. Sosial Budaya, 26.

Hidayat, D. R. 2011. Teori dan Aplikasi: Psikologi Kepribadian Dalam Konseling. Bogor: Penerbit Ghalia Indonesia.

Ida, R. 2014. Metode Penelitian Studi Media dan Kajian Budaya. Jakarta: Prenada Media Group.

Ismail, D. A. 2012. Agama Nelayan. Yogyakarta: Pustaka Pelajar.

Jung, C. G. 2018. Manusia dan Simbol-Simbol. Nurrohmah, Trans.). Yogyakarta: Basabasi. 
Jurnal Ilmu Budaya, Vol. 16, No. 2 Februari Tahun 2020

Moleong, L. 2013. Metodologi Penelitian Kualitatif. Bandung: Remaja Rosdakarya.

Pals, L. D. 2011. Seven Theories of Religion. Yogyakarta: IRCiSoD. 